\title{
Evaluation of quality of life, depression and satisfaction in patients treated at the Physiotherapy teaching clinic of the State University of Northern Paraná (Uenp)
}

\author{
Avaliação da qualidade de vida, depressão e satisfação com \\ o atendimento de pacientes atendidos na clínica-escola de \\ Fisioterapia da Universidade Estadual do Norte do Paraná (Uenp)
}

Evaluación de la calidad de vida, depresión y satisfacción con la atención de pacientes atendidos en la clinica-escuela de fisioterapia de la Universidad Estatal del Norte de Paraná (Uenp)

Jéssica Maria Marcusso Orsini ${ }^{[a]}\left(\mathbb{C}\right.$, Joyce Karla Machado da Silva ${ }^{[a]}(\mathbb{C}$, Marcos da Cunha Lopes Virmond ${ }^{[\mathrm{b}]}(\mathbb{0})$, Camila Costa de Araujo ${ }^{[a]} \mathbb{1}^{*} *$

[a] Universidade Estadual do Norte do Paraná (Uenp), Jacarezinho, PR, Brazil

[b] Universidade do Sagrado Coração (USC), Bauru, SP, Brazil

\section{Abstract}

Introduction: Patient satisfaction is an important indicator of care quality and can be used to set goals and identify areas for improvement. Objective: To evaluate the satisfaction, quality of life and depressive symptoms of patients at the Uenp (State University of Northern Paraná) Physiotherapy teaching clinic. Method: Cross-sectional, quantitative descriptive study. Sixty-one patients completed a sociodemographic questionnaire, the "Instrument to assess patient satisfaction with physical therapy in the public health system", the short-form-36 health survey (SF-36) to evaluate quality of life, and the Beck Depression Inventory (BDI) to determine the presence of depression. For statistical analysis, data were described using means and standard deviations, the Shapiro-Wilk test was applied

* JMMO: BS, e-mail: jehorsini@gmail.com JKMS: PhD, e-mail: jksilva@uenp.edu.br MCLV: PhD, e-mail: mvirmond@ilsl.br CCA: PhD, e-mail: camilaaraujo@uenp.edu.br 
to assess normality, and the variables were analyzed by Pearson's correlation coefficient, with $\mathrm{p} \leq 0.05$ considered statistically significant. Results: The patient-therapist relationship was largely classified as "excellent"; the most common response for the item "respect and interest shown to patients" was also "excellent". Patients scored well on the SF-36, indicating good quality of life; the highest scores were obtained in the "mental health" domain (65.04 \pm 23.25$)$. Regarding the depression, most patients (52.44\%) displayed depressive symptoms. Correlation between satisfaction and the BDI showed a statistically significant difference in twelve dimensions. Comparison between the SF-36 and BDI indicated a statistically significant difference in eight domains. Conclusion: Patients are satisfied with the treatment received and the competence of the health care team at the clinic.

Keywords: Quality of Life. Patient Satisfaction. Healthcare Evaluation. Depression.

\section{Resumo}

Introdução: A satisfação do paciente é importante na medida da qualidade da atenção prestada, sendo possível, através dela, traçar objetivos para alcançar as expectativas e indicar quais aspectos precisam melhorar. Objetivo: Avaliar a satisfação dos pacientes da clínica-escola de Fisioterapia da Universidade Estadual do Norte do Paraná, sua qualidade de vida e quadros depressivos. Método: Pesquisa transversal, quantitativa, de caráter descritivo. No total, 61 pacientes responderam ao questionário sociodemográfico, "Instrumento para aferir a satisfação do paciente com a assistência fisioterapêutica na rede pública de saúde", questionário de qualidade de vida SF-36 e o Inventário de Depressão de Beck (BDI) para verificar a presença de depressão. Para análise estatística, descreveu-se as médias e desvios padrões, realizou-se o teste de normalidade de Shapiro-Wilk e analisou-se as variáveis através da Correlação de Pearson, estatisticamente significante quando $p \leq 0,05$. Resultados: A relação terapeuta-paciente foi majoritariamente classificada como "excelente"; a resposta mais comum para o item "respeito e interesse com que os pacientes são tratados" também foi "excelente". O SF-36 obteve pontuação boa, indicando boa qualidade de vida; o domínio "saúde mental" foi o mais pontuado $(65,04 \pm 23,25)$. Quanto à depressão, a maioria dos pacientes $(52,44 \%)$ apresentaram quadros depressivos. Houve diferença estatisticamente significante quando se correlacionou a satisfação e o BDI em doze dimensões. Na correção do SF-36 com o BDI, houve diferença estatisticamente significante em oito domínios. Conclusão: Os usuários estão satisfeitos com o serviço prestado, apontando uma opinião homogênea positiva sobre a competência do trabalho realizado pela equipe na clínica.

Palavras-chave: Qualidade de Vida. Satisfação do Paciente. Avaliação em Saúde. Depressão.

\section{Resumen}

Introducción: La satisfacción del paciente es importante para la calidad de la atención prestada, pues es posible trazar objetivos para lograr las expectativas e indicar qué aspectos necesitan mejorar. Objetivo: Evaluar la satisfacción, calidad de vida y cuadros depresivos de pacientes de la clínica de Fisioterapia de la Universidad Estadual do Norte do Paraná. Método: Investigación transversal, cuantitativa, carácter descriptivo. 61 pacientes respondieron el: cuestionario sociodemográfico, cuestionario "Instrumento para medir la satisfacción del paciente con la asistencia fisioterapéutica en la red pública de salud", cuestionario de calidad de vida SF-36 e Inventario de Depresión de Beck (BDI). Para el análisis estadístico, se describieron las medias y desviaciones estándar, se realizó la prueba de normalidad de Shapiro-Wilk, y se analizaron las variables utilizando la Correlación de Pearson, estadísticamente significante cuando $p \leq 0,05$. Resultados: La relación terapeuta-paciente se clasificó principalmente como "excelente"; así como la respuesta más común al ítem "respeto y preocupación con que tratan a los pacientes". El SF-36 obtuvo una buena puntuación, indicando una buena calidad de vida; el dominio "salud mental" fue el más puntuado $(65,04 \pm 23,25)$. En cuanto a la depresión, la mayoría de los pacientes (52,44\%) presentaron cuadros depresivos. Hubo diferencia estadísticamente significativa cuando se correlacionó la satisfacción y el BDI en doce dimensiones. En la corrección del SF-36 con BDI, hubo diferencia estadísticamente significativa en ocho dominios. Conclusión: Los usuarios están satisfechos con el servicio prestado apuntando una opinión homogénea positiva sobre la competencia del trabajo realizado por el equipo en la clínica.

Palabras chave: Calidad de Vida. Satisfacción del Paciente. Evaluación en Salud. Depresión. 


\section{Introduction}

The use of questionnaires to assess user satisfaction became popular in Europe and in the United States in the 1960s, primarily with a view to evaluating treatment adherence [1] and was incorporated as a tool in health care quality in the 1970s and 1980s [2]. In Brazil, satisfaction surveys only gained traction in the mid-to-late 1990s, when the population became more involved in planning and assessment $[3,4]$.

Health care quality is directly linked to user satisfaction with how their needs are met [5]. Satisfaction can be defined as a positive response to different dimensions of health care services [6] and varies when patients' expectations and opinions change, even when the object of comparison, in this case being the treatment received, remains the same. As such, satisfaction encompasses the infrastructure of the facility as well as the treatment received and its outcome, making it a set of factors that go beyond the clinical setting [7]. Patient satisfaction surveys are an important tool in qualifying these services, even though satisfaction is related to personal and social values [8].

Physical therapy promotes individual and collective well-being and is capable of preventing, treating and rehabilitating kinetic disorders that affect the human body and organs, resulting from genetic alterations, trauma and disease [9]. It uses its own knowledge and resources as a component in the treatment of physical and psychosocial conditions to improve quality of life [10]. Treatment can be provided through teaching clinics affiliated with higher education institutions that offer care services to the public, provided by the final year graduate students supervised by a professor specialized in the field [11]. This gives the general population access to physical therapy free of charge.

Certain peculiarities of physiotherapy influence patient satisfaction, such as the fact that treatment takes longer than a routine clinical visit because it involves physical contact, and patients must actively participate in sessions [7].

Other important factors associated with patient satisfaction are quality of life and the presence or absence of depressions, both of which are closely linked to the general condition of patients.

The term quality of life (QoL) can be used in two settings: (1) in everyday language by the general population, journalists, politicians, professionals from a range of areas, and public policy managers; (2) in different fields of scientific research, including economy, sociology, education, medicine, nursing, psychology and other health care areas [12]. The World Health Organization (WHO) defines QoL as "an individual's perception of their position in life in the context of the culture and value systems in which they live and in relation to their goals, expectations, standards and concerns [13].

Depression is defined as a mental disorder characterized by sadness, loss of interest or pleasure, tiredness, low self-esteem, poor concentration, disturbed sleep or appetite, and feelings of guilt. Although depressive symptoms are common, especially at difficult times, depression is only diagnosed when symptoms have been present for at least two weeks [14].

Treating patients with physical disabilities should take motor, emotional and social sequelae into account since they generally exhibit depressive symptoms, high levels of anxiety, extreme dependence on others, impatience, irritability and aggressive behavior, among other psychological reactions. This occurs as a reaction to the prospect of dying, the difficulty in understanding what actually happened, the uncertainty of a possible relapse, and their changing role in the family, society and workplace [15]. Additionally, patients with clinical diseases and depression are at greater risk of noncompliance with medical recommendations [16].

The psychological difficulties experienced by these patients may directly or indirectly affect their clinical condition and as a result, physical therapists should view their patients as a whole person, treating both their mind and body [17].

In light of the above, this study aimed to assess patient satisfaction with physical therapy provided at the teaching clinic of the State University of Northern Paraná (Uenp), obtain their sociodemographic profile, and evaluate their quality of life and possible depressive symptoms.

\section{Methods}

\section{Participants}

This is a cross-sectional, quantitative descriptive study approved by the institutional Research Ethics Committee under protocol 2.527.267. 
The population consisted of 130 patients cared for at the Physical Therapy teaching clinic, which treats around the same number of patients every month. The assessment was conducted from March to July 2018. Inclusion criteria were users of both sexes, older than 18 , who had attended at least ten physical therapy sessions. Those who had difficulty in expressing themselves and/or understanding instructions, did not want to participate or refused to provide written informed consent were excluded from the study. Patient availability was also a determining factor, since most relied on transport provided by the City Council, with fixed arrival and departure times from the clinic. This made it impossible for some patients to answer the questionnaires because they arrived exactly on time for their sessions and left immediately afterwards. Based on the exclusion criteria, 18 patients were excluded for being underage, 16 due to cognitive or speech deficits and 34 because of conflicts with their scheduled transport times. The final sample consisted of 61 patients who gave written informed consent.

Assessments were carried out in the form of questionnaires applied by the researcher or completed by the patients themselves, before or after their physical therapy session.

\section{Instruments}

The sociodemographic questionnaire [18] contained questions on age, sex, schooling level, marital status, municipality of residence, employment, pension, household income, religious beliefs, any chronic diseases, among others.

The patient satisfaction survey, proposed by Moreira [19] and entitled "Instrument to assess patient satisfaction with physical therapy in the public health system" (Instrumento para aferir a satisfação do paciente com a assistência fisioterapêutica na rede pública de saúde in Portuguese)" contains two sections, one descriptive with 11 questions to characterize the sample, and the other objective, with 32 questions addressing different dimensions of patient satisfaction. The response options for 30 of the questions were very poor, poor, good, very good and excellent. The remaining two questions assessed whether patients would return to the clinic and recommend it to family and friends, with the response options being never, no, maybe, yes and definitely. In order to quantify and analyze the answers, the following scores were attributed to responses: very poor/never 1; poor/no 2; good/ maybe 3; very good/yes 4; excellent/definitely 5 .

The Medical Outcomes Study 36-Item Short-Form (MOS SF-36) survey is the most widely used generic quality of life questionnaire in both patient research and the population in general [20]. It contains 36 questions grouped into eight dimensions: physical functioning (10 items), physical role functioning (4 items), bodily pain ( 2 items), general health perceptions (5 items), vitality (4 items), social role functioning ( 2 items), emotional role functioning (3 items), mental health (5 items) and a comparative question assessing current health and health one year before $[21,22]$. The items in each dimension are coded, grouped and converted into a scale from 0 (worst health) to 100 (best heath).

The Beck Depression Inventory [23] is used by health care professionals and researchers in different clinical and research contexts [24]. It contains 21 items that address sadness, pessimism, sense of failure, dissatisfaction, feelings of guilt, punishment, self-dislike, self-accusation, suicidal ideas, crying, irritability, social withdrawal, indecisiveness, body image change, work difficulty, insomnia, fatigability, loss of appetite, weight loss, somatic preoccupation, and loss of libido, with intensity varying from 0 to 3 (absent, mild, moderate and severe) [25]. Scores vary from 0 to 63 , in which the higher the score the more severe the depression.

\section{Statistical analysis}

Statistical analyses were performed using BioEstat software version 5.3, with data described using means, standard deviations and percentiles. The Shapiro-Wilk test was applied, and the variables analyzed via Pearson's correlation coefficient, with statistical significance set at $\mathrm{p} \leq 0.05$. The correlation coefficients used were: $0<\mathrm{r}<0.25$ or $-0.25<\mathrm{r}<0=$ minor or zero correlation; $0.25<\mathrm{r}<0.50$ or $-0.50<\mathrm{r}<-0.25=$ weak correlation; $0.50<\mathrm{r}<0.75$ or $-0.75<\mathrm{r}<-0.50=$ moderate correlation; $0.75<\mathrm{r}<1.00$ or $-1<\mathrm{r}<-0.75=$ strong or perfect correlation [26].

\section{Results}

Table 1 presents a summary of patients' sociodemographic data. Of the total sample, $67.21 \%$ were women, average age was $54.13 \pm 15.21,52.45 \%$ of patients were married and most of them (37.7\%) had a high school diploma, with $86.88 \%$ reporting a 
household income of up to three minimum monthly wages (one minimum monthly wage $\approx$ USD 400.00 ) and $78.68 \%$ residing in the city of Jacarezinho, Paraná state (PR) (headquarters of the teaching clinic).

Table 1 - Relative frequency of patients' sociodemographic data

\begin{tabular}{|c|c|c|}
\hline Data assessed & $\mathbf{n}$ & $\%$ \\
\hline \multicolumn{3}{|l|}{ Sex } \\
\hline Female & 41 & $67.21 \%$ \\
\hline Male & 20 & $32.79 \%$ \\
\hline \multicolumn{3}{|l|}{ Marital status } \\
\hline Married & 32 & $52.45 \%$ \\
\hline Single & 13 & $21.32 \%$ \\
\hline Widow(er) & 13 & $21.32 \%$ \\
\hline Separated & 2 & $3.27 \%$ \\
\hline Cohabitation & 1 & $1.64 \%$ \\
\hline \multicolumn{3}{|l|}{ Schooling level } \\
\hline Incomplete elementary education & 14 & $22.95 \%$ \\
\hline Complete elementary education & 5 & $8.2 \%$ \\
\hline Incomplete high school education & 9 & $14.75 \%$ \\
\hline High school diploma & 23 & $37.7 \%$ \\
\hline College & 6 & $9.84 \%$ \\
\hline Illiterate & 4 & $6.56 \%$ \\
\hline \multicolumn{3}{|c|}{ Household income (in minimum wages) } \\
\hline 1 to 3 & 53 & $86.89 \%$ \\
\hline 4 to 6 & 6 & $9.84 \%$ \\
\hline 7 to 10 & 2 & $3.27 \%$ \\
\hline More than 10 & 0 & $0 \%$ \\
\hline \multicolumn{3}{|l|}{ City of residence } \\
\hline Jacarezinho-PR & 48 & $78.69 \%$ \\
\hline Cambará-PR & 6 & $9.84 \%$ \\
\hline Carlopólis-PR & 3 & $4.92 \%$ \\
\hline Ribeirão Claro-PR & 2 & $3.27 \%$ \\
\hline Andirá-PR & 1 & $1.64 \%$ \\
\hline Santo Antônio da Platina-PR & 1 & $1.64 \%$ \\
\hline
\end{tabular}

With respect to clinical knowledge and experience with physical therapy, $59.01 \%(n=36)$ of patients were referred by their doctors, 59.01\% ( $\mathrm{n}=36$ ) had undergone physical therapy before and $83.6 \%$ $(n=51)$ were visiting the clinic for the first time.

In relation to clinical diseases, $24.59 \%$ had rheumatic disorders associated with other chronic diseases (systemic hypertension (SHT), diabetes, depression) and $21.32 \%$ exhibited neurological conditions and other chronic disorders. Among the patients studied, $57.37 \%(\mathrm{n}=35)$ were treated in orthopedics and $42.62 \%(n=26)$ in neurology.

Figure 1 presents a summary of responses related to the patient-therapist relationship, collected via the patient satisfaction survey. None of patients viewed this relationship as poor or very poor. Respect and interest shown to patients was the item most frequently scored as excellent (75.30\%), followed by "confidence in the recommendations given" (72.13\%). The item least scored as excellent was "language used by the physical therapist", at $57.39 \%$.

Regarding hygiene and care provided by other team members, responses varied from good to very good and excellent, with $70.50 \%$ of patients scoring the availability of other team members as excellent (Figure 2). The item addressing how easy patients found it to schedule a session was rated good and all the questions assessing the facilities at the clinic achieved the maximum score, except for "general conditions at the clinic", which $42.65 \%$ of participants scored as very good. "Comfortable waiting room" was also rated very good by most participants.

With respect to quality of life assessed by the SF-36, patients obtained an average total score of $91.61 \pm 17.29$ points. The domain with the highest score was mental health $(65.04 \pm 23.25)$, followed by social role functioning $(61.70 \pm 26.18)$, vitality (57.78 \pm 23.84$)$, general health perceptions (56.06 \pm 14.43), emotional role functioning $(45.27 \pm 37.59)$; bodily pain $(43.83 \pm 23.12)$, physical functioning $(29.91 \pm 22.62)$ and physical role functioning $(29.91 \pm 22.62)$.

On the Beck Depression Inventory (BDI), $47.54 \%(\mathrm{n}=29)$ showed no depressive symptoms; however, regardless of their classification (mild, moderate or severe), $52.46 \%$ of patients ( $\mathrm{n}=32$ ) displayed some form of depression, with an average score of $11.80 \pm 8.21$ for all respondents (indicating mild depression).

Correlation between scores on the patient satisfaction survey and the BDI showed a statistically significant difference in the confidence conveyed during treatment, confidence in the recommendations given, attention paid to patient's complaints, kindness and availability of the other team members, ability to easily schedule a physical therapy session, convenience of session times, clinic location, transportation to the clinic, comfortable waiting room, ability to easily move around the clinic, and possibility of being treated by the same physical therapist (Table 2).

In regard to the coefficient of correlation, a zero correlation $(0<\mathrm{r}<0.25$ or $-0.25<\mathrm{r}<0)$ was only recorded between details provided in the physical therapist's analysis and the BDI, with a weak correlation for the remaining items $(0.25<\mathrm{r}<0.50$ or $-0.50<\mathrm{r}<-0.25$ ) (Table 2). 
-Excellent $\quad$ Very good $\quad$ Good

Clear explanations provided in the first session

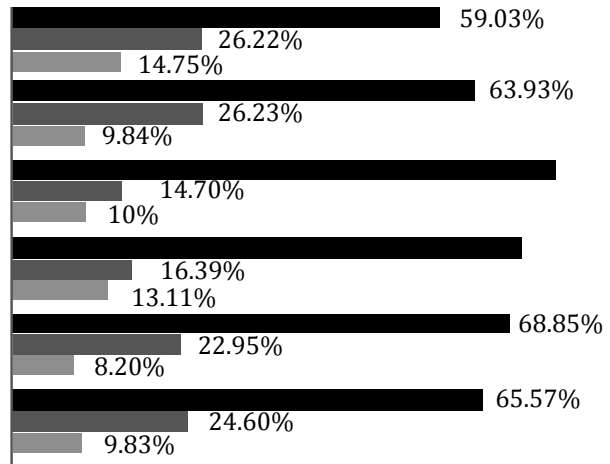

Confidence in the recommendations given

Attention paid to your complaints

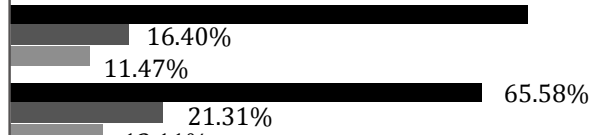

Opportunity for you to express your opinion

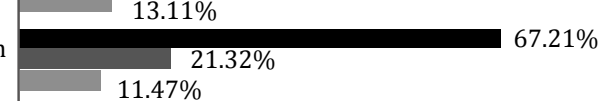

Competence of the physical therapist

In-depth evaluation of your case
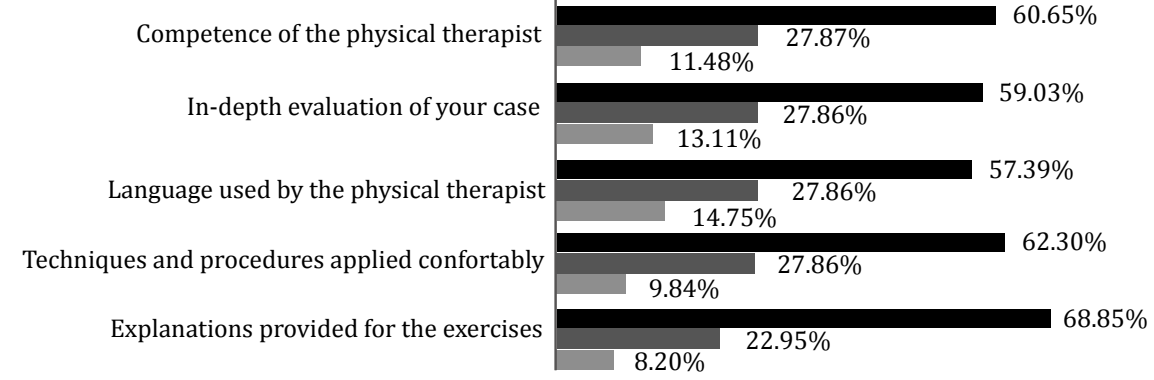

Figure 1 - Responses to the dimensions assessing the patient-therapist relationship.

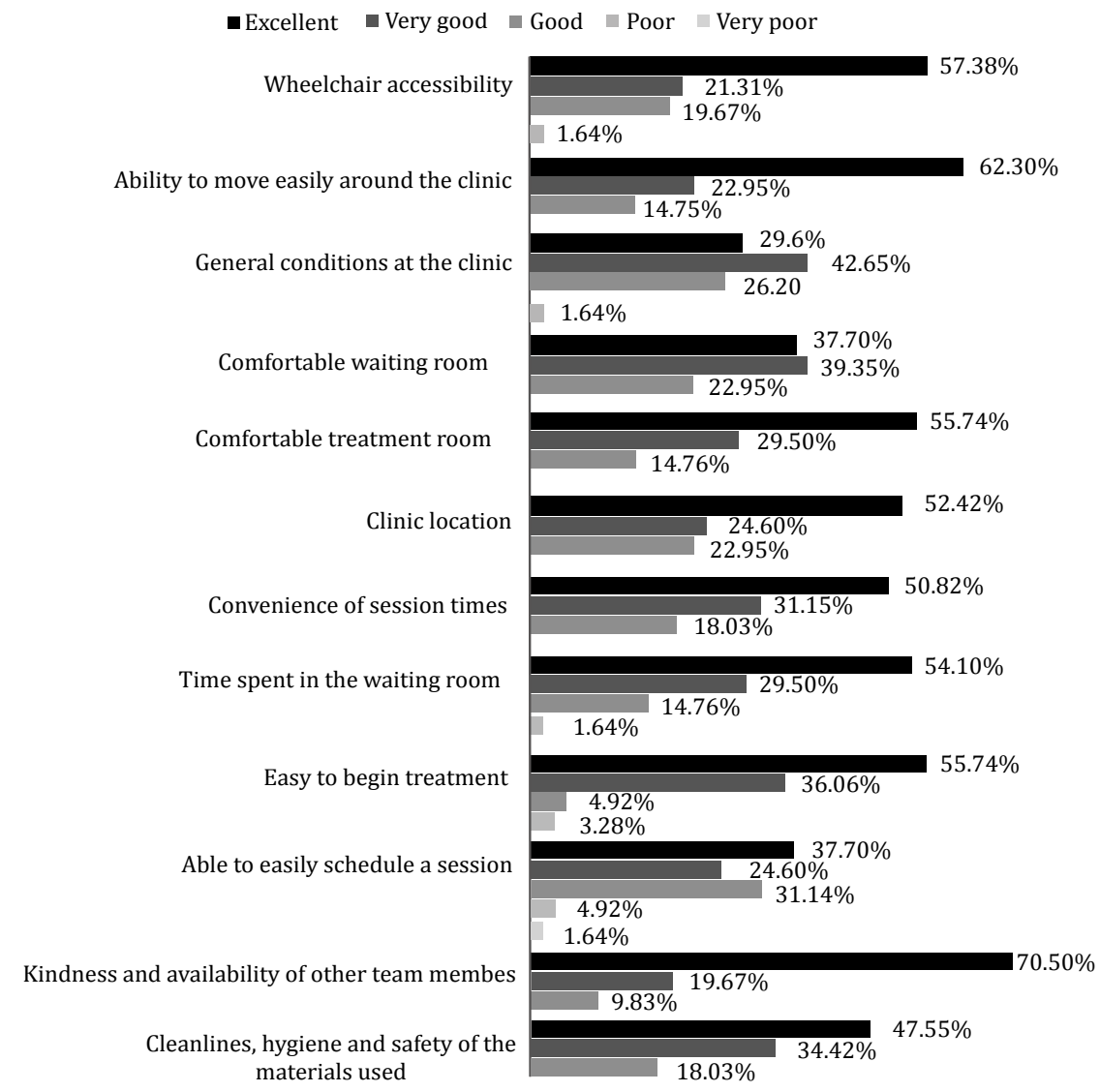

Figure 2 - Hygiene, care provided by other team members, wheelchairaccessibility of the clinic and facilities provided. 
Table 2 - Pearson’s correlation between the patient satisfaction survey and Beck Depression Inventory (BDI)

\begin{tabular}{lcc}
\hline \multicolumn{1}{c}{ Correlation } & $\mathbf{p}$ & $\mathbf{p}$ \\
\hline Confidence conveyed during treatment $\times \mathrm{BDI}$ & -0.2791 & $0.02^{*}$ \\
Confidence in the recommendations given $\times \mathrm{BDI}$ & -0.3434 & $0.006^{*}$ \\
Attention paid to patient's complaints $\times \mathrm{BDI}$ & -0.3734 & $0.003^{*}$ \\
Competence of the physical therapist $\times \mathrm{BDI}$ & -0.2910 & $0.02^{*}$ \\
Kindness and availability of the other team members $\times \mathrm{BDI}$ & -0.2737 & $0.03^{*}$ \\
Details provided in the physical therapist's analysis $\times \mathrm{BDI}$ & -0.2437 & 0.058 \\
Ability to easily schedule a session $\times$ BDI & -0.3219 & $0.01^{*}$ \\
Convenience of session times $\times$ BDI & -0.3461 & $0.006^{*}$ \\
Clinic location $\times$ BDI & -0.3265 & $0.01^{*}$ \\
Transportation to the clinic $\times$ BDI & -0.3429 & $0.006^{*}$ \\
Comfortable waiting room $\times$ BDI & -0.2981 & $0.01^{*}$ \\
Ability to easily move around the clinic $\times$ BDI & -0.3254 & $0.01^{*}$ \\
Possibility of being treated by the same physical therapist $\times$ BDI & -0.2685 & $0.03^{*}$ \\
\hline
\end{tabular}

Note: ${ }^{*}=p \leq 0.05$

Correlation between the BDI and SF-36 dimensions showed a statistically significant difference in physical functioning, bodily pain, general health perceptions, vitality, social role functioning, emotional role functioning, mental health, as well as the total score (Table 3).

For the correlation coefficient, a zero correlation $(0<\mathrm{r}<0.25$ or $-0.25<\mathrm{r}<0)$ was only observed between the BDI and physical role functioning. Physical functioning, bodily pain, general health perceptions, vitality, social and emotional role functioning showed a weak correlation $(0.25<\mathrm{r}<0.50$ or $-0.50<\mathrm{r}<-0.25$ ), whereas mental health and total score exhibited a moderate correlation $(0.50<\mathrm{r}<0.75$ or $-0.75<\mathrm{r}<-0.50$ ) (Table 3).

Table 3 - Pearson's correlation between the Beck Depression Inventory (BDI) and SF-36 domains

\begin{tabular}{lcc}
\hline \multicolumn{1}{c}{ Correlation } & $\mathbf{r}$ & $\mathbf{p}$ \\
\hline BDI $\times$ Physical functioning & -0.3737 & $0.003^{*}$ \\
BDI $\times$ Physical role functioning & -0.1868 & 0.14 \\
BDI $\times$ Bodily pain & -0.3797 & $0.002^{*}$ \\
BDI $\times$ General health perceptions & -0.4259 & $0.0006^{*}$ \\
BDI $\times$ Vitality & -0.4997 & $<0.0001^{*}$ \\
BDI $\times$ Social role functioning & -0.4378 & $0.0004^{*}$ \\
BDI $\times$ Emotional role functioning & -0.3550 & $0.005^{*}$ \\
BDI $\times$ Mental health & -0.5554 & $<0.0001^{*}$ \\
BDI $\times$ Total score & -0.6382 & $<0.0001^{*}$ \\
\hline
\end{tabular}

Note: ${ }^{*}=p \leq 0.05$.

\section{Discussion}

Based on the sociodemographic profile, most participants had low income levels, with a household income of 1 to 3 minimum wages. The same findings were reported by Viana et al. [27], with $87.8 \%$ of patients reporting low earnings. As such, teaching clinics are an option for people who cannot afford private treatment or require longer treatment, which is the case of chronic diseases [11].

The sample in this study consisted primarily of women (67.21\%), probably because the combination of domestic and professional tasks predisposes them to musculoskeletal complications, as reported by Machado and Nogueira [28].

With respect to referral, $59 \%$ of users heard about the clinic from their doctors. The same results were obtained by Guzzo and Fassicollo [29], Cattani et al. [30] and Viana et al. [27], indicating that physical therapists are being more seriously viewed by the medical community in terms of patient rehabilitation [27].

Patients rated how easy it was to schedule a physical therapy session as good, possibly because the clinic has a long waiting list due to its affiliation with the Norte Pioneiro Intermunicipal Public Health Consortium (Cisnorpi), which covers patients referred to physical therapy by doctors from the Brazilian National Health System (SUS) in 25 municipalities in the region.

In terms of satisfaction, most participants rated the patient-therapist relationship as excellent and the item that obtained the highest score was "respect and interest shown to patients", corroborating the findings of Suda et al. [11], who studied patients at the teaching clinic of the Universidade do Grande $\mathrm{ABC}$ (UniABC). The item least scored as excellent was "language used by the physical therapist". In a study by Silva et al. [31], the item least rated as excellent $(25 \%)$ addressed the clarity of explanations provided. 
Beattie et al. [32] reported that answering all the patient's questions, providing information and being respectful are the elements most related to satisfaction, demonstrating the importance of patient-therapist interaction. These findings support the concept that patients' perception regarding the quality of their relationship with their physical therapist, particularly in exchanging relevant information, is a vital component in their satisfaction with the treatment.

Balica et al. [33] surveyed the satisfaction of patients treated at a clinic in Caxias, Maranhão state (MA), whose opinion regarding other members of the health care term was generally very good (40.32\%), whereas this item was classified as excellent in our study. Dias et al. [34] also reported good as the highest rating for how easy patients found it to schedule sessions (32\%), corroborating this study.

The average total score of participants in the SF-36 was $91.61 \pm 17.29$ points. Aquino et al. [21] evaluated quality of life among physical therapy patients at basic health units and recorded a mean and standard deviation of $72.81 \pm 17.83$ after intervention. Accacio [35] investigated the presence of depression and its impact on the quality of life of patients treated at the physical therapy teaching clinic of the Methodist University of São Paulo and found worse QoL in those with rheumatic disorders when compared to neurological conditions, with average total scores of 46 and 56 points, respectively. As observed in this study, Accacio [35] reported the highest scores in the mental health domain, which addresses how respondents felt in the last four weeks: nervous, depressed, calm, peaceful, despondent, happy [36].

Although mental health exhibited the highest scores, most patients displayed some form of depression. Berber et al. [37] reported that depression significantly compromised physical functioning, physical role functioning, bodily pain and social and emotional role functioning. As such, the mental health domain may not have been influenced by depression, possibly because one questionnaire deals with feelings in the last week while the other investigates the previous four weeks.

There was an important correlation between satisfaction and depression, suggesting that the emotional state of patients can affect how they react to the treatment provided. Given that depression is the most common mental health issue, it may contribute to the functional impairment and poor quality of life present in $10 \%$ and $15 \%$ of patients, respectively [36]. Based on the results obtained, patients were satisfied with the treatment provided by the teaching clinic, despite exhibiting depressive symptoms. This may be because patients interact with other users when they attend their physical therapy sessions, receiving additional attention from the physiotherapist and other staff members at the clinic (also evident in the results of the satisfaction survey). As a result, patients feel welcomed during their sessions and the emotional bond created fulfills their emotional needs, improving their psychological state.

Medeiros et al. [38] analyzed patient satisfaction with treatment for musculoskeletal conditions and found a negative and statistically significant correlation between clinical improvement and patient satisfaction, whereby satisfaction with the treatment seems to be independent of their satisfaction with the clinical outcomes obtained.

In this study, comparison between the SF-36 and BDI showed a statistically significant correlation for physical functioning, bodily pain, general health perceptions, vitality, social and emotional role functioning, mental health, and total score, with no correlation for physical role functioning. In line with our study, Accacio [35] also found no correlation for physical role functioning or physical functioning. A study made by Capela et al. [39] observed a negative correlation between quality of life and bodily pain, anxiety and depression, indicating that the more severe the symptoms, the worse the quality of life. The presence of depressive symptoms resulted in greater absenteeism, lower productivity and worse quality of life for patients [40]. According to Berber et al. [37], depression has a negative effect on quality of life because it exacerbates feelings of pain and physical impairment, making treatment adherence more difficult and compromising social relationships. This demonstrates that depression influences all domains of the SF-36.

\section{Conclusion}

Patients were satisfied with their care, particularly in terms of the patient-therapist relationship, indicating they were confident and secure with the treatment provided by the interns. The sociodemographic profile obtained showed that most patients had a low-income level, making the free-of-charge treatment received at the clinic vitally important. In general, patients displayed good quality of life, with the highest scores recorded in the mental health domain. Despite being satisfied with their treatment, most participants exhibited depressive 
symptoms. Regarding the correlations observed, both satisfaction and quality of life were directly affected by patients' psychological state.

\section{References}

1. Ware JE Jr, Snyder MK. Dimensions of patient attitudes regarding doctors and medical care services. Med Care. 1975;13(8):669-82.

2. Turris SA. Unpacking the concept of patient satisfaction: a feminist analysis. J Adv Nurs. 2005;50(3):293-8.

3. Aharony L, Strasser S. Patient satisfaction: what we know about and what we still need to explore. Med Care Rev. 1993;50(1):49-79.

4. Sitzia J, Wood N. Patient satisfaction: a review of issues and concepts. Soc Sci Med. 1997;45(12):1829-43.

5. Carvalho VL, Cavalcante DM, Santos LPD, Pereira MD. Satisfação dos pacientes atendidos no estágio curricular de fisioterapia na comunidade. Fisioter Pesqui. 2013;20(4):330-5.

6. 6. Gonçalves JR, Veras FEL, Matos ACM, Lima ISA. Avaliação da satisfação dos pacientes submetidos à intervenção fisioterapêutica no município de Campo Maior, PI. Fisioter Mov. 2011;24(1):47-56.

7. Brito TA, Jesus CS, Fernandes MH. Fatores associados à satisfação dos usuários em serviços de fisioterapia. Rev Baiana de Saude Publica. 2012;36(2):514-26.

8. Fréz AR, Nobre MIRS. Satisfação dos usuários dos serviços ambulatoriais de fisioterapia da rede pública. Fisioter Mov. 2011;24(3):419-28.

9. Magalhães MS, Sousa FJP. Avaliação da assistência fisioterapêutica sob a óptica do usuário. Fisioter Bras. 2004;5(5):350-6.

10. 0 que é fisioterapia? Crefito 9. 2012 Nov 14 [cited 2018 Aug 31] Available from: http://bit.ly/2jZuDtz

11. Suda EY, Uemura MD, Velasco E. Avaliação da satisfação dos pacientes atendidos em uma clínicaescola de fisioterapia de Santo André, SP. Fisioter Pesqui. 2009;16(2):126-31.
12. Seidl EMF, Zannon CMLC. Qualidade de vida e saúde: aspectos conceituais e metodológicos. Cad Saude Publica. 2004;20(2):580-8.

13. The World Health Organization quality of life assessment (WHOQOL): position paper from the World Health Organization. Soc Sci Med. 1995;41(10):1403-9.

14. Organização Mundial de Saúde. Relatório sobre a saúde no mundo 2001: saúde mental: nova concepção, nova esperança. Geneva; 2001.

15. Oliveira RA. Psicologia clínica e reabilitação física. Lisboa: Ed. Instituto Superior de Psicologia Aplicada; 2001.

16. DiMatteo MR, Lepper HS, Croghan TW. Depression is a risk factor for noncompliance with medical treatment: meta-analysis of the effects of anxiety and depression on patient adherence. Arch Intern Med. 2000;160(14):2101-7.

17. Moreira LMA. A prevalência de alterações emocionais e a sua relação com o bem-estar físico e qualidade de vida nos utentes da Clínica Pedagógica de Fisioterapia da Universidade Fernando Pessoa [undergraduation project]. Porto: Universidade Fernando Pessoa; 2013.

18. Zumpano, CE. Tradução, adaptação transcultural e validação do banco de itens saúde global do patientreported outcomes measurement information system - PROMIS - para a língua portuguesa [thesis]. Uberlândia: Universidade Federal de Uberlândia; 2015.

19. Moreira CF, Borba JAM, Mendonça KMPP. Instrumento para aferir a satisfação do paciente com a assistência fisioterapêutica na rede pública de saúde. Fisioter Pesqui. 2007;14(3):37-43.

20. Hemingway H, Stafford M, Stansfeld S, Shipley M, Marmot M. Is the SF-36 a valid measure of change in population health? BMJ. 1997;315(7118):1273-9.

21. Aquino CF, Augusto VG, Moreira DS, Ribeiro S. Avaliação da qualidade de vida de indivíduos que utilizam o serviço de fisioterapia em unidades básicas de saúde. Fisioter Mov. 2009;22(2):271-9. 
22. Ware JE, Gandek B. The SF-36 health survey: development and use in mental health research and the IQOLA project. Int J Ment Health. 1994;23(2):49-73.

23. Beck AT, Ward CH, Mendelson M, Mock J, Erbaugh J. An inventory for measuring depression. Arch Gen Psychiatry. 1961;4(6):561-71.

24. Beck AT, Steer RA. Beck depression inventory manual. San Antonio: Psychological Corporation; 1993.

25. Gorestein $\mathrm{C}$, Andrade L. Inventário de depressão de Beck: propriedades psicométricas da versão em português. Rev Psiquiatr Clin. 1998;25(5):245-50.

26. 26. Vieira S. Introdução à bioestatística. Rio de Janeiro: Elsevier; 2011.

27. Viana JRS, Raiocovitch T, Golias AR, Peternella FMN, Mendes FCV, Grabowski J. Avaliação da satisfação com a fisioterapia de pacientes atendidos em uma clínica escola de Maringá-PR. Uninga Rev. 2014;17(2):16-21.

28. Machado NP, Nogueira LT. Avaliação da satisfação dos usuários de serviços de Fisioterapia. Rev Bras Fisioter. 2008;12(5):401-8.

29. Guzzo S, Fassicollo CE. Avaliação da satisfação dos usuários de serviços de fisioterapia na clínica escola de pesquisa e atendimento em fisioterapia (Cepaf) da Universidade do Oeste de Santa Catarina (Unoesc). EFDeportes.com. 2011;16(163).

30. Cattani IC, Borrille RL, Traverso MED. Avaliação da satisfação dos usuários de fisioterapia em uma clínica-escola de uma universidade do meio-oeste catarinense. Fisioterapia em Ação. 2016:27-38.

31. Silva JFS Jr, Araújo SP, Nava AV, Dias RS. Serviço prestado em uma clínica-escola: fatores influentes na satisfação dos pacientes. Saude e Pesqui. 2014;7(1):129-34.

32. Beattie P, Turner C, Dowda M, Michener L, Nelson R. The MedRisk instrument for measuring patient satisfaction with physical therapy care: a psychometric analysis. J Orthop Sports Phys Ther. 2005;35(1):24-32.
33. Balica SCP, Silva IRC, Luz KRG, Sousa FCA. Avaliação da satisfação dos pacientes em uma clínica de saúde de fisioterapia em Caxias-MA. REAS. 2016;8(2):861-7.

34. Dias AO, Souza CB, Porto GM, Gomes NCP, Soares TK, Carreiro DL, et al. Avaliação da satisfação dos usuários em relação ao atendimento fisioterapêutico prestado em clínica escola. Rev EFDeportes.com. 2011;15(153):4-8.

35. Accacio LMP. A presença de depressão em pacientes durante o período de reabilitação física e o impacto na qualidade de vida dos mesmos [thesis]. São Bernardo do Campo: Universidade Metodista de São Paulo; 2004.

36. Wood-Dauphinee S. Assessing quality of life in clinical research: from where have we come and where are we going? J Clin Epidemiol. 1999;52(4):355-63.

37. Berber JSS, Kupek E, Berber SC. Prevalência de depressão e sua relação com a qualidade de vida em pacientes com síndrome da fibromialgia. Rev Bras Reumatol. 2005;45(2):47-54.

38. Medeiros FC, Costa LOP, Oliveira NFC, Costa LCM. Satisfação de pacientes que recebem cuidados fisioterapêuticos para condições musculoesqueléticas: um estudo transversal. Fisioter Pesqui. 2016;23(1):105-10.

39. Capela C, Marques AP, Assumpção A, Sauer JF, Cavalcante AB, Chalot SD. Associação da qualidade de vida com dor, ansiedade e depressão. Fisioter Pesqui. 2009;16(3):263-8.

40. Sharovsky LL, Gonçalves SCS, Vieira PR, Camargo N, Soares L, Romano BW. A percepção do paciente sobre a adesão à medicação antidepressiva. Estud Interdiscip Psicol. 2013;4(1):2-14.

Received in 12/06/2018

Recibido em 06/12/2018

Recibido en 06/12/2018

Approved in 07/22/2019

Aprovado em 22/07/2019

Recibido en 22/07/2019 